\title{
Checklist and description of three new chromatic patterns of Pachycoris torridus (Scopoli, 1772) (Hemiptera: Scutelleridae)
}

\author{
Tatiani Seni de Souza-Firmino ${ }^{1,2}$, Kaio Cesar Chaboli Alevi ${ }^{1}$, Luis Lenin Vicente Pereira ${ }^{I}$, \\ Cecilia Artico Banho ${ }^{I}$, Fernando Cesar Silva Junior ${ }^{I}$, Emi Rosane Silistino de Souza ${ }^{I}$ \& \\ Mary Massumi Itoyama ${ }^{1}$ \\ ${ }^{I}$ Instituto de Biociências, Letras e Ciências Exatas, Departamento de Biologia, São José do Rio Preto, \\ SP, Brazil. \\ ${ }^{2}$ Corresponding author: Tatiani Souza-Firmino,e-mail: tatseni@hotmail.com
}

SOUZA-FIRMINO, T.S., ALEVI, K.C.C., PEREIRA, L.L., BANHO, C.A., SILVA JUNIOR, F.C., SOUZA, E.R.S., ITOYAMA, M.M. Checklist and description of three new chromatic patterns of Pachycoris torridus (Scopoli, 1772) (Hemiptera: Scutelleridae). Biota Neotropica. 16(1): e20140195. http://dx.doi.org/10.1590/1676-0611-BN-2014-0195

\begin{abstract}
In the present paper, 27 chromatic patterns of the specie Pachycoris torridus (Scopoli, 1772) were grouped and three new patterns are described. Because of this high phenotypic polymorphism, $P$. torridus already been registered eight times as a new specie, highlighting the importance of the application of different tools to assist in taxonomy of this hemipterous of economic importance.
\end{abstract}

Keywords: Insect, Heteroptera, polymorphism, agricultural pest.

SOUZA-FIRMINO, T.S., ALEVI, K.C.C., PEREIRA, L.L., BANHO, C.A., SILVA JUNIOR, F.C., SOUZA, E.R.S., ITOYAMA, M.M. Checklist e descrição de três novos padrões cromáticos de Pachycoris torridus (Scopoli, 1772) (Hemiptera: Scutelleridae). Biota Neotropica. 16(1): e20140195. http://dx.doi.org/ 10.1590/1676-0611-BN-2014-0195

Resumo: No presente artigo, 27 padrões cromáticos da espécie Pachycoris torridus (Scopoli, 1772) são agrupados e três novos padrões são descritos. Devido a esse grande polimorfismo fenotípico, $P$. torridus já foi registrado oito vezes como espécie nova, o que ressalta a importância da aplicação de diferentes ferramentas para auxiliar na taxonomia desse hemíptero de importância econômica.

Palavras-chave: Insecta, Heteroptera, polimorfismo, peste agrícola.

\section{Introduction}

The insects of the Scutelleridae family are popularly known as shield-backed bug, due to its scutellum which covers the whole body (Grazia \& Schwertner 2011). A striking feature of Scutelleridae is intraspecific phenotypic variability, as can be observed in the species Poecilocoris lewisi (Distant, 1883), Pachycoris klugii (Burmeister, 1835) and Pachycoris torridus (Scopoli, 1772) (Miyamoto \& Kosaku 2002, Peredo 2002). Pachycoris species are very similar to each other, although few differences exist among their genitalia and measure of scutellum and head (Peredo, 2002).

The stink bug $P$. torridus is phytophagous and polyphagous that has great prominence as an agricultural pest, with records of their attacks in 16 vegetable crops (Marques et al., 2012), with emphasis on the cultures of physic nut (Jatropha curcas Linnaeus 1753), raw material for the production of biodiesel (Borges Filho et al. 2013). This hemipterous is longevous and can live out to 600 days (Gabriel \& Franco, 2012), with wide distribution in the Neotropical region. Shows a wide variation in chromatic patterns, characteristic that made $P$. torridus be registered several times as a new species (Costa Lima 1940), getting names like: Tetyra schousboei (Fabricius, 1803), Pentatoma fabricii (Tigny 1801),
Scutellera decorate (Perty, 1833), Pachycoris Klungii (Burmeister, 1835), Pachycoris linaei (Westwood in F. W. Hope 183), Pachycoris Aquila (Herrich-S. 1839), Pachycoris stallii (Uhler 186) and Poecilocoris aeneiventris (Vollenhoven, 1863) (Maes 1994).

Monte (1937) initiated the descriptions of stains patterns of this stink bug and registered 13 different patterns, terming standard 1 to 13 . The author highlights the pattern 13 (Figure 1) as the basic for $P$. torridus. Currently, there are 27 chromatic patterns described for this hemipterous in different scientific articles (Monte 1937, Sanchez-Soto 2004, Santos et al. 2005, Pikart 2011, Souza et al. 2012). Thus, in this study we performed a checklist of all the patterns of stains described in the literature for $P$. torridus and we describe three new (Figure 2).

\section{Material and Methods}

The checklist of twenty-seven chromatic patterns described for P. torridus was compiled from the literature (Monte 1937, SanchezSoto 2004, Santos et al 2005, Pikart 2011, Souza et al. 2012). For description of three new patterns, specimens of $P$. torridus were collected in Brotas, Sao Paulo, Brazil (22 $\left.{ }^{\circ} 14^{\prime} 17.6^{\prime \prime} \mathrm{S}, 48^{\circ} 07^{\prime} 56.0^{\prime \prime} \mathrm{W}\right)$ in Jatropha curcas Linnaeus (1753). The description was based on 


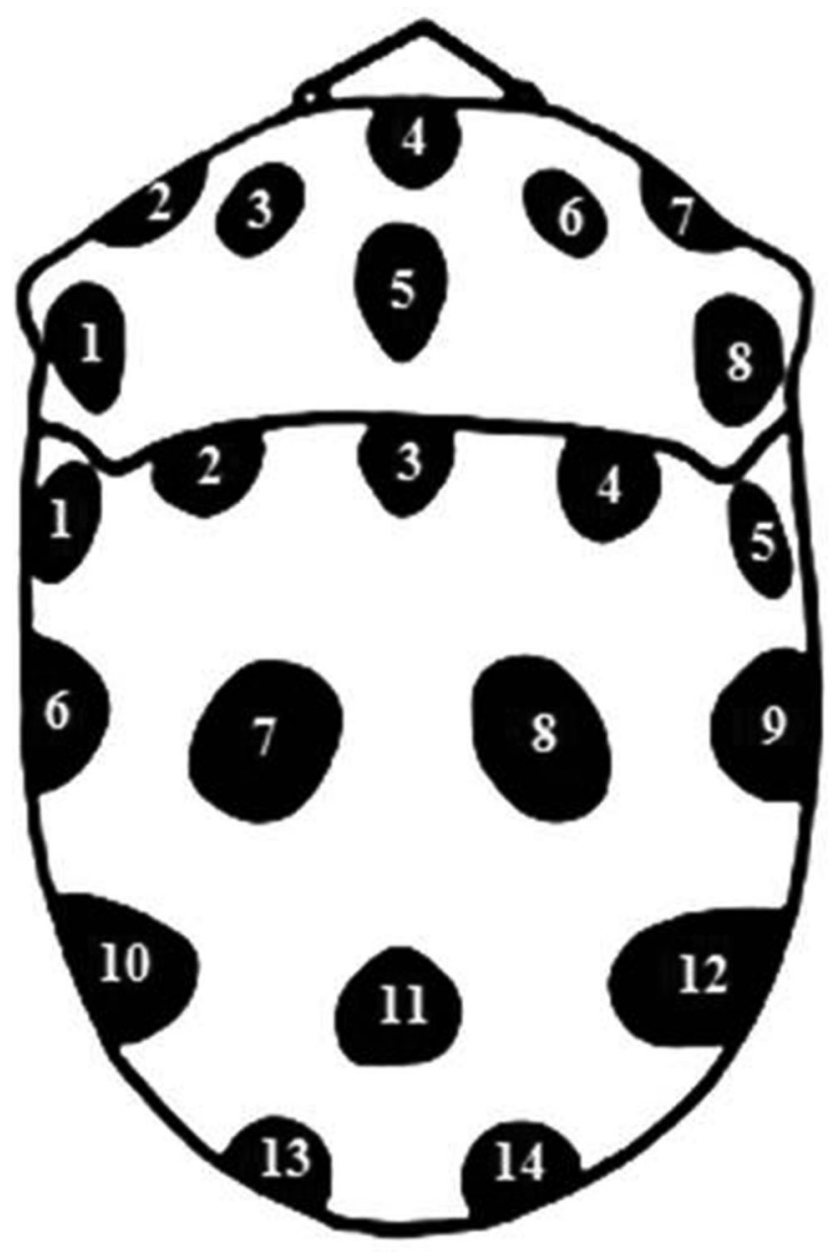

Figure 1. Basic pattern of $P$. torridus described by Monte (1937), with 22 spots, being 8 on pronotum and 14 on scutellum.

basic pattern of spots described by Monte (1937). Vouchers were deposited in the collection of the Laboratory of Cytogenetics and Molecular of Insects, of Institute of Biosciences, letters and the Exact Sciences (UNESP/IBILCE), Sao Jose do Rio Preto, Sao Paulo, Brazil.

\section{Results}

The stink bugs of the specie Pachycoris torridus are globular, with scutellum very developed, showing different patterns of stains and colors of its body, the coloring of the spots vary of yellow to red. In this checklist, 27 chromatic patterns identified for this species are detailed and ilustrated (Figure 3), according to the information of its publication, classified with pattern 1 to 27 th in the order which they were reported. Three new chromatic patterns are described on this paper, totalizing one list with 30 chromatic patterns for this insect.

Pattern 1. Features 15 spots. Pronotum with six, being two near the head, two on the sides and two in the posterior region, and scutellum with nine, arranged in four rows, respectively 2, 4, 2 and 1 spots starting from the base to the apex (Monte 1937).

Pattern 2. Features 4 spots. Pronotum and scutellum with two spots, both of paired (Monte 1937).

Pattern 3. Features 8 spots. Pronotum with four, being two in the middle region disposed in parallel and two on the sides, and scutellum with four, arranged in three rows, being the last with two spots (Monte 1937).

Pattern 4. Features 16 spots. Pronotum with six, arranged in two rows with 2 and 4 stains, respectively, and scutellum with ten spots, arranged in four rows of 2, 2, 4 and 2 spots each, starting from the base to the apex (Monte 1937).

Pattern 5. Features 14 spots. Pronotum with four, being two rows with two spots each, and scutellum with ten, arranged in four rows of 2, 2, 4 and 2 spots, respectively, from base to apex (Monte 1937).

Pattern 6. Features 12 spots. Pronotum with six, being two near the head, two on the sides and two in the posterior region, and scutellum with six, arranged in three rows of 1, 4, 1 stains, being one big spot next to the base region (Monte 1937).

Pattern 7. Features 15 spots. Pronotum with six, being two near the head, two on the sides and two in the posterior region, and scutellum with nine, arranged in four rows with 2, 4, 2 and 1 spots, respectively, from base to apex (Monte 1937).

Pattern 8. Features 7 spots. Pronotum with two big spots, and scutellum with five, being one big in the region near the base, two on the sides and two near the apex (Monte 1937).

Pattern 9. Features 2 spots. Pronotum and scutellum with one big spot on each, featuring the spaces that would be the spots on basic pattern (Figure 1) (Monte 1937).
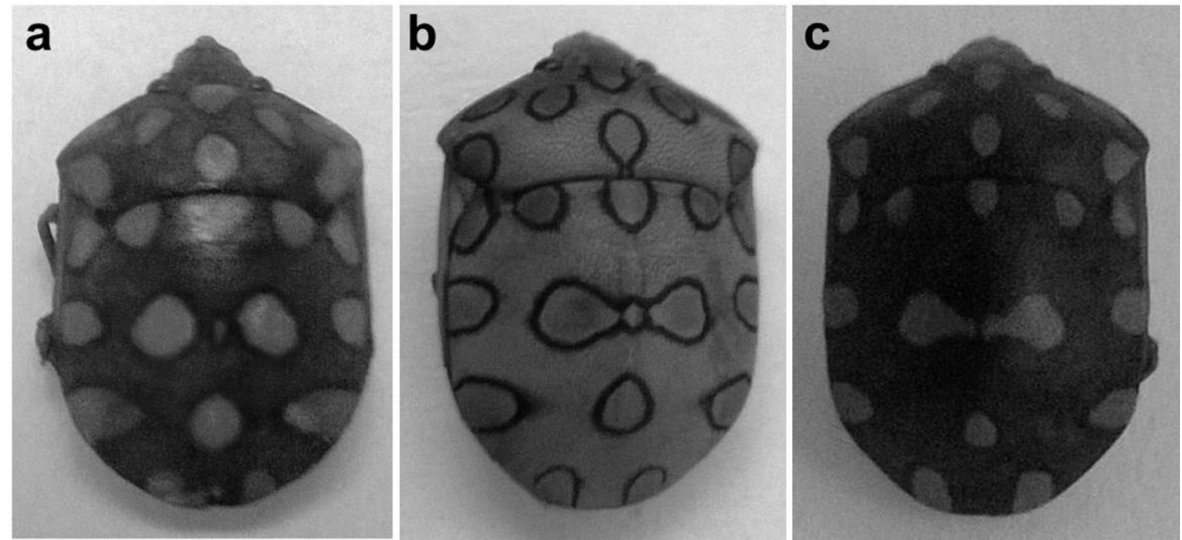

Figure 2. New chromatics patterns observed in the present work. a) Pattern 28; b) Pattern 29; c) Pattern 30. 

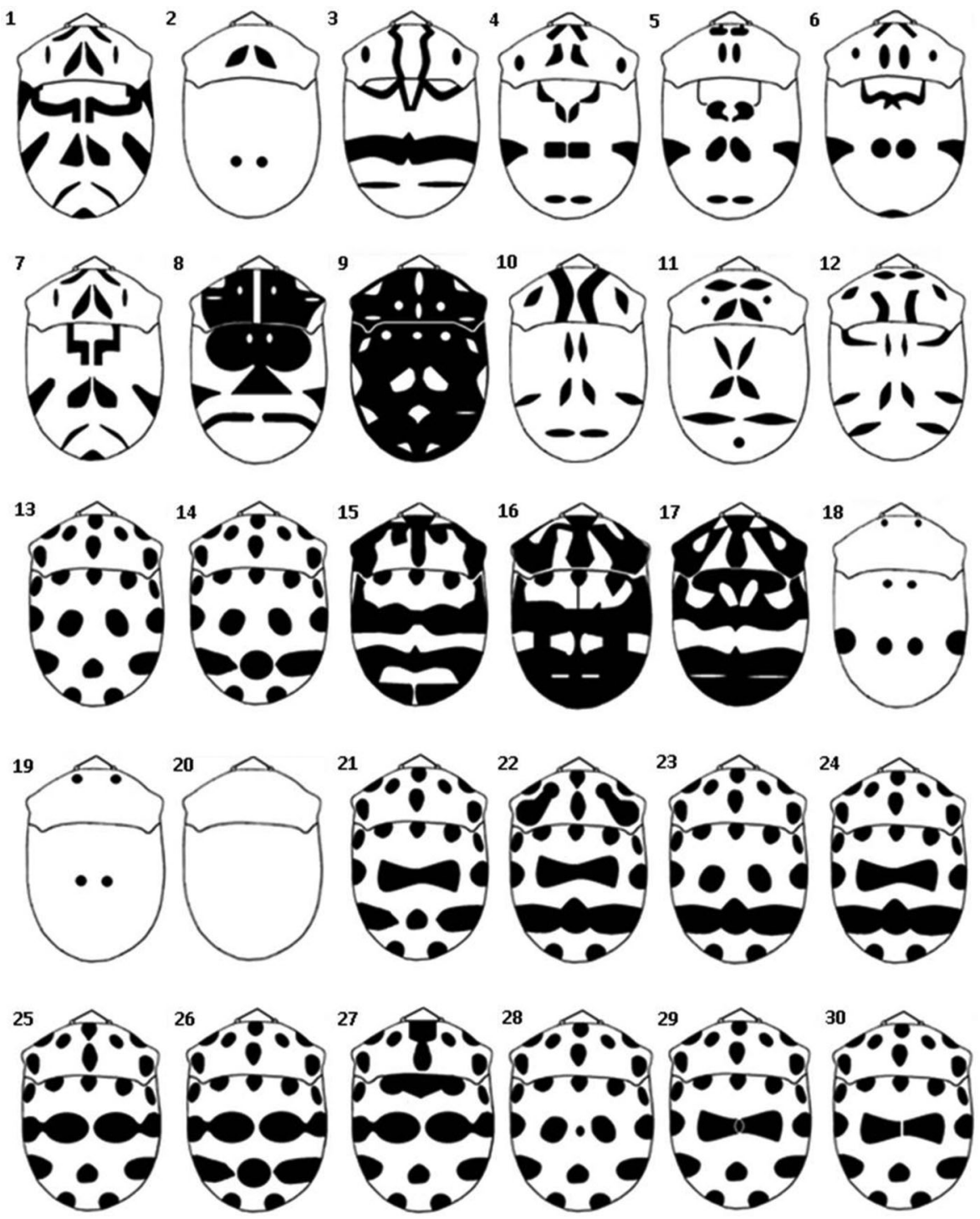

Figure 3. Schemes of 30 chromatic patterns of $P$. torridus. In black the spots.

Pattern 10. Features 12 spots. Pronotum with four, being two in the middle, and two on the sides, and scutellum with eight, arranged in three rows with 2, 4 and 2 spots each (Monte 1937).

Pattern 11. Features 13 spots. Pronotum with six, being two near the base, two near the apex and two on the sides, and scutellum with seven, arranged in four rows with 2, 2, 2 and 1 spots respectively from base to apex (Monte 1937).

Pattern 12. Features 16 spots. Pronotum with six, being two near the base, two near the apex and 2 on the sides, and scutellum with ten, arranged in three rows of 4, 4 and 2 spots, respectively, from the base to the apex (Monte 1937).

Pattern 13. Features 22 spots. Pronotum with eight spots, and scutellum with fourteen, neatly arranged in four rows, respectively of 5, 4, 3 and 2 spots from base to apex (Monte 1937).

Pattern 14. Features 22 spots. Pronotum with eight spots, and scutellum with fourteen, with the spots 10, 11 and 12 higher than the basic pattern (Figure 1) and very close together (Sanchez-Soto et al. 2004).
Pattern 15. Features 6 spots. Pronotum with a single spot, the eight spots of the basic pattern (Figure 1) joined from lateral and anterior margins, and scutellum with five spots, the spots 1, 6, 7, 8, 9 and 5, joined and formed a continuous strip, and spots $10,11,12,13$ and 14 joined leaving a small space near the apex (Sanchez-Soto et al. 2004).

Pattern 16. Features 3 spots. Pronotum with one spot, formed by the union of the eight spots of the basic pattern (Figure 1), and scutellum with two spots, one is the spot 2 of the basic pattern (Figure 1), and the other formed by the union of spots 1, 3, 4, 5, 6, 7, 8, 9, 10, 11, 12, 13 and 14 (Sanchez-Soto et al. 2004).

Pattern 17. Features 3 spots. Pronotum with one spot, formed by the union of the 8 spots of the basic pattern (Figure 1 ), and scutellum with two spots formed by the union of spots $1,2,3,4,5,6,7,8$ and 9, near the base, and spots 10, 11, 12, 13 and 14 near the apex (Sanchez-Soto et al. 2004).

Pattern 18. Features 8 spots. Pronotum with two near the head, and scutellum with six, being two near the base, two on median region, and two on the sides (Santos et al. 2005). 
Pattern 19. Features 4 spots. Pronotum with two near the head, and scutellum with two on the medium region (Santos et al., 2005).

Pattern 20. Without spots (Santos et al., 2005).

Pattern 21. Features 21 spots. Pronotum with eight spots, and scutellum thirteen, with the spots 7 and 8 of the basic pattern joined (Figure 1) and the spots 10 and 12 larger than the basic pattern (Pikart et al. 2011).

Pattern 22. Features 17 spots. Pronotum with six, being spots 1 and 8 of the basic pattern (Figure 1) joined, respectively, with the spots 3 and 7, and scutellum with eleven, presented the spots 7 and 8 united, and spots 10, 11 and 12 joined forming a continuous strip (Souza et al. 2012).

Pattern 23. Features 20 spots. Pronotum with eight, and scutellum with twelve, the spots 10,11 and 12 of the basic pattern (Figure 1) joined forming a continuous strip (Souza et al. 2012).

Pattern 24. Features 19 spots. Pronotum with eight spots, and scutellum with eleven, the spots 7 and 8 of the basic pattern joined (Figure 1) and spots 10,11 and 12 grouped forming a continuous strip (Souza et al. 2012).

Pattern 25. Features 20 spots. Pronotum with eight spots, being the spots 4 and 5 very close together, and scutellum with 12 , being the spots 6 and 9 joined, respectively, with spots 7 and 8 (Souza et al. 2012).

Pattern 26. Features 20 spots. Pronotum with eight spots, and scutellum with twelve, the spots 6 and 7 joined, as well as the spots 8 and 9, and the spots 10,11 and 12 are larger and closer together (Souza et al. 2012).

Pattern 27. Features 17 spots. Pronotum with seven, the spots 4 and 5of basic pattern joined (Figure 1), and scutellum with ten, the spots 2, 3 and 4 grouped near the base forming a continuous strip and spots 6 and 9 joined, respectively, with spots 7 and 8 (Souza et al. 2012).

Pattern 28. Features 23 spots. Pronotum with eight spots, and scutellum fifteen, with one additional spot between the spots 7 and 8 of the basic pattern (Figure 1). (This paper) (Figure 2a).

Pattern 29. Features 21 spots. Pronotum with eight spots, and scutellum with thirteen, the spots 7 and 8 of the basic pattern joined (Figure 1) (This paper) (Figure 2b).

Pattern 30. Features 22 spots. Pronotum with eight spots, and scutellum with fourteen, the spots 7 and 8 are larger and closer together, that the basic pattern (Figure 1) (This paper) (Figure 2c).

\section{Discussion}

The stink bug $P$. torridus shows different phenotypes with several variations in the pattern of spots and colors of your body, however, all their phenotypic diversity had not been described. Monte (1937) iniciated the disciption of this species and recorded 13 different patterns in 13 of 16 specimens collected on an unidentified plant. He depicted the basic chromatic patterns of this stink bug as being one that presents 22 spots, being eight in the pronotum and 14 in the scutellum, neatly arranged in the scutellum where present in four rows respectively of 5, 4, 3 and 2 spots, starting from the base to the apex. The color of the spots is diversified, varying of red to yellow (Monte, 1937). Years later, Sanchez-Soto et al. (2004) recorded in Schinus terebinthifolius Raddi (1820) more four patterns; Santos et al. (2005) more three in Cnidoscolus pubescens Pohl (1827); Pikart et al. (2011) described a new pattern in Coffea arabica Linnaeus (1737) and, Souza et al. (2012) described six patterns with specimens collected in Jatropha curcas Linnaeus (1753). In this article we performed a checklist of the 27 color patterns described and we describe three new patterns, completing a list of 30 color patterns described for $P$. torridus.

The high polymorphism of $P$. torridus already led to great taxonomic mistakes, with this species described eight time as new (Costa Lima 1940). According to Monte (1937), the color variations of $P$. torridus are not hereditary and the factors that may contribute to the differentiation of a color are diverse and complex, however the factors involved in the polychromatism of $P$. torridus have not yet been identified.

Grazia \& Schwertner (2011) in a checklist about biodiversity of the State of Sao Paulo, Brazil, emphasized that the Scutelleridae family needs of taxonomic revision and highlighted the importance of the developing of tools to identification and dissemination of the knowledge of the group. Souza et al. (2012) also emphasize that the high chromatic variation of $P$. torridus makes necessary to describe new phenotypes to assure its correct taxonomic identification. Souza-Firmino et al. (2014) described the presence of $P$. torridus in 15 Brazilian states and emphasized their infestations in the culture of physic nut and they highlight the characteristic of polyphagous of $P$. torridus, which allows this insect can colonize and mainly become an agricultural pest to other crops of economic importance.

Thus, because of this great importance as agricultural pest, this great phenotypic variability and due the scarcity of information about this insect, the checklist and description of three new chromatic patterns of $P$. Torridus, is a new tool for taxonomy of this stink bug, synthesizing all the chromatic patterns described for the specie.

\section{Conclusion}

This article makes, for the first time, one checklist of all the chromatic patterns described for the specie $P$. torridus and fundament the patterns already described in descriptions initial contained in scientific articles. Thus, this study enabled us to identified the high chromatic polymorphism of this stink bug.

\section{Acknowledgments}

This research was supported by Fundação de Apoio à Pesquisa e Extensão de São José do Rio Preto (FAPERP) and Conselho Nacional de Desenvolvimento Científico e Tecnológico $(\mathrm{CNPq})$.

\section{References}

BORGES FILHO, R.C., PRATISSOLI, D., NAVA, D.E., MONTE, F.G., GUIDONI, A.L., SILVA, S.D.A. \& POLANCZYK, R.A. 2013. Development of Pachycoris torridus (Hemiptera: Scutelleridae) on Jatropha curcas (Euphorbiaceae), Psidium cattleianum (Myrtaceae) and Aleurites fordii (Euphorbiaceae). Fla. Entomol. 96 (3), 1149-1157, http://dx.doi.org/10.1653/024.096.0356.

COSTA LIMA, A.C. 1940. Insetos do Brasil. Hemipteros. Série Didática Núm. 3 Escola Nacional de Agronomia. Rio de Janeiro. cap.22, tomo 2, 351p.

GABRIEL, D. \& FRANCO, D.A.S. 2012. Aspectos biológicos e morfológicos de Pachycoris torridus Scopoli, 1772 (Hemiptera: Scutelleridae) criados com pinhão-manso Jatropha curcas L., 1753, 
em laboratório. Científica, 40:156-163, http://dx.doi.org/10.15361/ 1984-5529.2012v40n2p156+-+163.

GRAZIA, J. \& SCHWERTNER, C.F. 2011. Checklist dos percevejos-domato (Hemiptera: Heteroptera: Pentatomoidea) do Estado de São Paulo, Brasil. Biota Neotrop., vol. 11, http://dx.doi.org/10.1590/S167606032011000500034.

MAES, J.M. 1994. Catalogo de los Pentatomoidea (Heteroptera) da Nicaragua. Rev. Nicar. Entomol. 28:1-29.

MARQUES, O.M., ROSÁRIO, A.G., FRANÇA, E.S., CARVALHO, P.C.L. 2012. Ocorrência de Pachycoris torridus (Scopoli) (Hemiptera: Scutelleridae) no estado da Bahia, Brasil. Magistra, 24:207-209.

MIYAMOTO, K. \& KOSAKU, A. 2002. Cuticular Microstructures and Their Relationship to Structural Color in the Shieldbug Poecilocoris lewisi Distant. Forma, 17, 155-167.

MONTE, O. 1937. Algumas variações nos desenhos e cores de Pachycoris torridus (Scopoli). Campo, Rio de Janeiro, v.8, p.71.

PEREDO, L.C. 2002. Description, biology, and maternal care of Pachycoris klugii (Heteroptera: Scutelleridae). Fla Entomol., Gainesville, v. 85 , n. 3, p. 464-473, http://dx.doi.org/10.1653/0015-4040 (2002)085[0464:DBAMCO]2.0.CO;2.

PIKART, T.G., SOUZA, G.K., ZANUNCIO, T.V., SERRÃO, J.E. \& ZANUNCIO, J.C. 2011. New chromatic pattern and first register of Pachycoris torridus damaging Coffea arabica fruits in Viçosa, Minas Gerais State, Brazil (Hemiptera: Scutelleridae). Entomol. Gen. 33:207-211.

SANCHEZ-SOTO, S., MILANO, P. \& NAKANO, O. 2004. Nova planta hospedeira e novos padrões cromáticos de Pachycoris torridus (Scopoli) (Hemiptera: Scutelleridae) no Brasil. Neotrop. Entomol., Londrina, v. 33, n. 1, p. 109-111.

SANTOS, J.C., SILVEIRA, F.A.O., ALMEIDA, F.V.M. \& FERNANDES, G.W. 2005. Ecology and behavior of Pachycoris torridus (Hemiptera: Scutelleridae): new host plant, color polymorphism, maternal care and parasitism. Lundiana, Belo Horizonte, v.6, n.2, p.107-111.

SOUZA-FIRMINO, T.S., ALEVI, K.C.C., PEREIRA, L.L.V., BANHO, C.A., SILVA JUNIOR, F.C. \& ITOYAMA, M.M. 2014. Occurrence of Pachycoris torridus (Scopoli, 1772) (Hemiptera: Scutelleridae) on Physic Nut (Jatropha curcas) in Northwest of São Paulo, Brazil. Entomol. Ornithol. Herpetol, v. 3, n. 3, 1-3p, http:// dx.doi.org/10.4172/2161-0983.1000135.

SOUZA, G.K., PIKART, T.G., OLIVEIRA, H.N., SERRÃO, J.E., ZANUNCIO, J.C. 2012. Color polymorphism in Pachycoris torridus (Hemiptera: Scutelleridae) and its taxonomic implications. Rev. Chil. Hist. Nat., Santiago, v. 85, n. 3, 357-359p. 